\title{
An Examination on Adequacy of Law in India to Regulate and Monitor Media
}

\author{
Rameshkumar D, Jayaprakash D
}

\begin{abstract}
The two horrible conditions ahead of time than the organizers worldwide are to diminish the stack at the conventional fills and to reduce the continually developing basic spoiling. This test is proposed to discover probably the execution of the DI diesel motor at various loads when fuelled with mixes of palm methyl esters and diesel. The primers have been pushed on a completely utilized diesel motor without changes. Every one of the appraisals were consistent usa of america and outfitted toward dependable pace. The impact of moving weight develop to be assessed the volume that brake warm temperature ability, mass flow rate, brake one of a kind gas use and fumes gas temperature. Exploratory impacts show that at complete weight conditions, the B-20, B-40and B-60 mixes bring $33.23 \%, 32.81 \%$, $32.39 \%$ and 31.ninety seven\% higher brake heat usefulness than sole diesel freely. It wound up confirmed that the brake warmth ability of palm biodiesel is higher than that of diesel, and it is a delayed consequence of the oxygenated atom of biodiesel which acknowledges total ingesting of the biodiesel fuel. In addition the mass development rate of biodiesel is evidently superior to anything that of diesel fuel; it is through method for exact capacity of the calorific estimation of biodiesel is a ton parcels less appeared in one another way as far as diesel gas. At the reason for results obtained from this test utilizing palm biodiesel as a fuel is proposed for the utilized as a piece of a diesel motor with diesel mixes.
\end{abstract}

Catchphrases: biodiesel, esterification, pyrolysis, emulsification, blends.

\section{INTRODUCTION}

Communication is the necessity of life as a medium of thought propagation among human beings. It is the mode of logic and information exchange. The independent exchange of ideas and thought takes place through unrestricted multiway communication. Indian constitution guarantees the "freedom of speech andexpression "amended as the most eminent fundamental right. Freedom of speech has a wide periphery which includes holding opinions, freedom to impart information, freedom to receive information and freedom to express against the elected government. It is related to free will, thinking, imagination and deliberations. These are the most relevant ingredients of self-realization. Most of the thinkers consider freedom of speech on the topmost priority. These are mainly two roles entertained by freedom of speech which is to express one's thought process as the public understanding and another is to express own opinion as unique ideology. The only way to represent selfdetermination is by the means of voice and expression and its efficient demonstration to the world.

Revised Manuscript Received on 14 August, 2019.

Rameshkumar D, Ph.D. Research Scholar Department of Visual Communication, School of Mass Communication, Vels Institute of Science Technology and Advanced Studies (Deemed to be University), Chennai, Tamil Nadu, India.

Dr. Jayaprakash D, Associate Professor \& Head at Department of Visual Communication, Meenakshi Academy of Higher Education and Research (Deemed to be University), Chennai, Tamil Nadu, India.
The freedom of press and media deals with the efficient utilization of freedom of speech with and against even the government on public welfare. It is a reliable channel to bridge between public opinion and government performance. Freedom of speech is the main term responsible for successful debate over all the possible factors related to public importance. All over the globe everyone strongly believes that through media only the freedom of speech is actually exercised in full fledge. Media is the brain for the thought process of the public. In India watching the daily news is the routine process of most of the families.

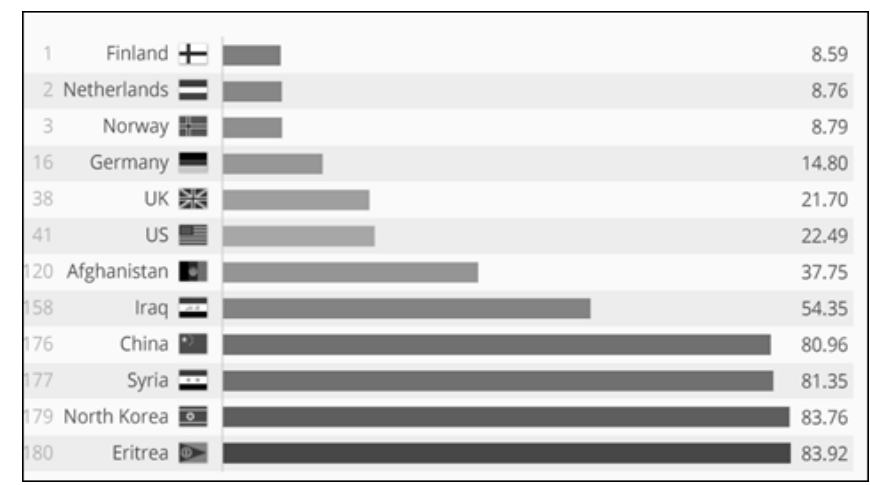

Fig.1:- Decline percentage in Media Freedom worldwide

As per the statistical report of statista organization in 2016, there is a huge decline in media freedom worldwide [1]. With increasing literacy percentage the media intervention in the thought process of Indian countrymen is kept increasing. What was mainly exercised in urban areas is now propagating in rural as well, i.e. media reach and its ability to sculpt the ideology of people. Media is an important eye over the government of the public for proper functionality and impartial actions. Media is the fourth lion face hidden in India Government symbol. It is responsible to have monitored over other branches of Indian government which are Executive, Legislature and Judiciary. The independent media allows the individuals to express their perspective over the matters disturbing them. It has been affirmed throughout the world that media with the autonomous capacity to endow countrymen on diverse information and perspective on matters of public interest. The liberty of media works in accordance with "Freedom of expression". The print and digital media provide the published information and if it of public information then it's the basic "human right" to know the facts. Print and digital media is the crucial platform which enables the people to know the performance of government, the monitory process, the state and several other matters which should be known by the public.

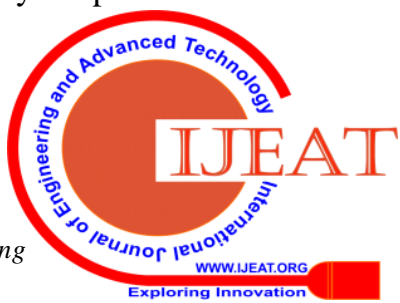




\section{LITERATURE SURVEY}

[1]. B. Mugundhan and C.Renuga stated in their Article on freedom of the press in India that democratic situation and judge in the society based on the privileges the free media receives in that state. The media is an external important parameter to monitor the efficient performance of

India being a country which governs the largest democracy of the world must have the freedom of media for the smooth functioning of the government. Though the court show very cleanly the freedom of press yet freedom of speech and expression needs to be reiterated.

[2]. Manoj Kumar Sadual expressed in his paper on freedom of the press in Indian constitution published in International Journal of Applied Research that the constitution of India did not notify the freedom of press explicitly. Freedom of the press is implied by Article 19(1)(a) of the constitution. Yet it is implied with restrictions under the clause (2) which states under several conditions like Integrity of India, the security of the state, affected relation with friend nations, contempt of court, defamation etc. the right is restricted. The paper was about the keen observation of freedom of the press in India on judicial context as well.

[3]. DaudaIshayaSuntai, AtandoDavida and Tordve Simon Targema explained in their paper about mass media freedom as per the survey in Nigeria media context. Their study interrogates media - states relationship under the ongoing situations in Nigeria. As per the reliable sources and studies, it was stated that there in moments exists of clashes between government and media, presently media holds the free authority to express the right situations. They also referred that social media propagation created the issue of hatred influence and needed the government to take strict actions to avoid unpleasant situations. They clearly explained that early start of present democratic dispensation saw some abuse to press freedom but now the situations have changed positively. The current era is so far much better compared to the military era when the pressmen were mistreated.

\section{RESEARCH CONTENT AND CONSIDERATIONS}

\section{A. Requirements for the Study}

- Media is the crucial requirement for public matters broadcast. Article 19 of the Indian constitution enables the "Freedom of Speech" for every citizen of India. Though it is not stated clearly in any of the six freedom terms of Article 19 about the freedom of the press.

- $\quad$ Right for Freedom of speech for media is always considered is the freedom of speech and expression only. It is not an explicit term. Media being a strong body to pass the information should have been got a strong position to freely express the vows and thoughts, whatever is important for the public to know about.

- In several countries, media does not own a stand mostly they are controlled or paid. Major countries where least degree of press freedom in Eritrea, Syria, Vietnam, China, North Korea and Turkmenistan. [5] We want to draw the public attention towards the working style of media and the democracy chosen controllers.

to check whether Indian media also receives such controls.

- Several countries media is under the control of the government in the time duration of one political ruling party but not during the rule of their opposition. Our study minutely monitors how the media subsystem works during the government time span. It is an important parameter and represents the mindset of the ruling government. If the government does not hold control over the rights of media it means it has good vows for the independent thought process. [6]

B. Objectives for the Study

- $\quad$ To study the ethics of the media in different parts of the world and the ongoingsituations faced by them.

- To identify the current status of the regulatoryframework of Indian Media and major concerns needed for their efficient functionality and impartial presentations of realtime scenario.

- To analyse the adequacy of regulations towards media.

- To provide suggestions to the government/law council for regulating the rules towards media.

\section{Research Process and Analysis}

- Several studies were done on recent scenarios and situations to understand the real situation of press and media in India. The resultant is based on realtime situations and considerations.

- An analytical study was used to analyse and compare the rules and regulations of many countries with Indian law towards Media.

- We have researched over the Kashmir Issue when all the connection medium were blocked in Kashmir to avoid rumour and riots.

\section{Recent Scenarios}

1. Kashmir Telecommunication, Mobile Data and Media Talks Suspension in Kashmir

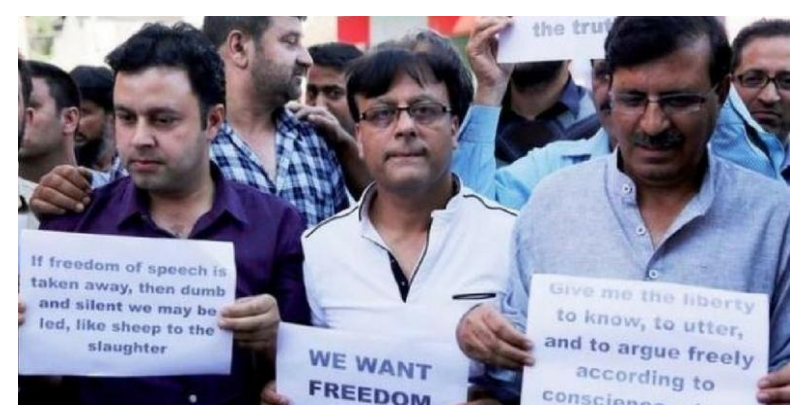

Fig.2:- Protest in Kashmir against media censorship

Just after the withdrawal of Article 370, there was a chance for major protest, sloganeering and riots in Kashmir valley. To avoid all these problems all the social and media houses were temporarily suspended in Kashmir. Many cases of fabricated incidences of protests by several thousand people were being displayed on media reports. 
To avoid all these misconceptions all the communication lines were stopped for a quiet longer duration. This is not the single case where freedom of media was kept hostage for a while. As per the report of Wikipedia [3] in an article "Censorship in Kashmir, "it was clearly stated that from 2012 to 2016 at least 31 times the internet connection of Kashmir was blocked. The censorship of media in Kashmir meant the hold over the press and social media both. The editor of Kashmir time requested the relaxation on all the censored independence of the media personnel in the action against the media in Some Parts of Jammu and overall Kashmir.

The stated they have the right to practice their media profession as per the Indian constitution Article 14, 19 (1) (a) and 19 (1) (g) and 21. These actions were prevention are precautions to avoid unwanted situation against a peaceful environment. General these actions were not imposed in any state and it was a case of emergency.

\section{REASON OF ACTIONS ON TIKTOK, WHATSAPP SOCIAL MEDIA \& RESULTS}

The major reason of TikTok and WhatsApp received strong actions by the Indian government due to several reasons like.

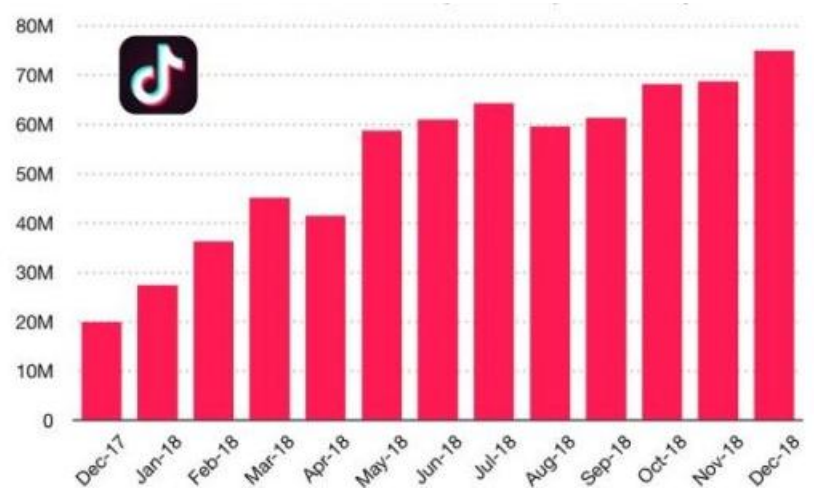

Fig.3:- TikTokInstalls worldwide in 2018

\section{For TikTok}

- $\quad$ Accident Due to videos being made by youth.

- Harassment by editingsomeone's video inappropriately

- $\quad$ On Cultural and pornographic videos on TikTok

- Google and Apple removed TikTok from their app store due to several complaints.

\section{For WhatsApp}

- $\quad$ All the Indian user data were maintained outside the country so in case of requirement, it was not produced. This used to create a lot of confusion and issues.

- There was no WhatsApp grievance officer in India which was very confusing as the representative of WhatsApp summoned by court was mostly not present.

Many Disciplinary actions were taken over several social and press media based on circumstances. There was a reason for all of that. If we think openly we find the actions were the last option.

\section{CONCLUSION}

Independent organizations like press and media always need a free will and social and democratic independence to publicise the authentic information. Their prime intention should be the honest information system for the country. The complete independence of media might create another issue of business competition in terms of false news. The scrutiny of media is important but to a certain extent. Till it does not affect the genuinity of media in India. So far after studying the media censorship incidences, it was clear that mostly it was applied during the extreme conditions where there was no last option. The actions were taken to avoid riots, confusions and social outrage. After considering all the parameters it was clearly identified that the media owns a very responsible task and they must take care of the genuinity of ideology

\section{REFERENCES}

1. https://www.statista.com/chart/4745/orld-press-freedomindex/

2. B.Mugundhan, C. Renuga, A study on freedom of press in India: with reference to article 19, International Journal of Pure and Applied Mathematics, Volume 120 No. 52018.

3. Manoj Kumar Sadual, Freedom of Press in Indian Constitution: A Brief Analysis, International Journal of Applied

4. Dauda Ishaya Suntai, Ph.D., Atando Dauda Agbu, Ph.D. and Tordue Simon Targema, Mass Media, Freedom of Expression and Democracy: The Nigerian Experience from 1999-2017, TSU Journal of Communication and Media Studies, Volume 1, Number 1, 2018.

5. https://en.wikipedia.org/wiki/Censorship_in_Kashmir

6. https://en.wikipedia.org/wiki/Freedom_of_the_press

7. Durga Das Basu, Law of the press, 4th edition, 2002 , Wadhwa and company, Nagpur.

8. Dr. JN Pandey, constitutional law of India, 44th edition, 2007, central law agency, Allahabad.

9. Dr. Madabhusi Sriddhar, The law of expression, 1st edition, 2007, Asia Law house, Hyderabad.

10. H.M. Seervai, constitutional law of India, 4th edition, 2007, universal law publishing company, New Delhi.

11. Madhavi Goradia divan, facets of media Law,Eastern book company, Lucknow.

12. Prof. Kailash Rai, The constitutional law of India, 8th edition, 2009,central Law publication Allahabad.

13. Prof. M.P.jain, Indian constitutional law, 5th edition, 2009, lexis Nevis butterworths Wadhwa, Nagpur.

14. VN. Shukhla, constitution of India, 10th edition, 2001,eastern book company, NewDelhi.

15. Markandey Katju. Freedom of the Press and Journalistic Ethics, the Hindu, June 2, 2011.

16. The 'Fourth Estate' is the public press, referred to as a collective and encompassing photographers, journalists, television broadcasters, and radio announcers, among others.

17. Nehru's speech on 20th June 1916 in protest against the press Act, 1910.

18. Brij Bhushan \& Another vs. The State of Delhi, AIR 1950 SC 129 ; Sakal Papers (P) Ltd vs. Union of India, AIR 1962 SC 305 
19. Dr.Lakshmi T and Rajeshkumar S , March. 2018. "In Vitro Evaluation of Anticariogenic Activity of Acacia Catechu against Selected Microbes", International Research Journal of Multidisciplinary Science \& Technology, Volume No. 3 , Issue No. 3, P.No 20-25.

20. Trishala A, Lakshmi T and Rajeshkumar S, April 2018.“ Physicochemical profile of Acacia catechu bark extract An In vitro study", International Research Journal of Multidisciplinary Science \& Technology, Volume No. 3 , Issue No. 4, P.No 26-30.

\section{AUTHORS PROFILE}

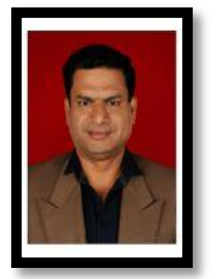

Mr. Rameshkumar D is pursuing his $\mathrm{PhD}$ in Mass Communication from Vels Institute of Science, Technology and Advanced Studies(Deemed to be University). He holds a Masters Degree in, Journalism andMass Communication fromMaduraiKamaraj University. He has completed LLB from Sri Venkateswara University (Thirupathi Andhra Pradesh). He has been working as a Legal Special Correspondent in leading Tamil channels for more than 20 years. He is currently associated with Sun TV network. He has been participating in legal and media-related law conferences.He has published several researchpapers in UGC Journals. His area of interest includes media trial and judicial processes.

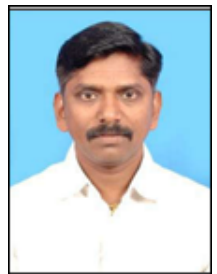

Dr. Jayaprakash D is an Associate Professor \& Head at Department of Visual Communication, Meenakshi Academy of Higher Education and Research (Deemed to be University), Chennai, India He has done his PhD from Department of Media Sciences, Anna University, Chennai, India. He has published several research papers, a book chapter and book on various aspects of Media Studies. He specializes in Digital Cultures, Film Cultures, Broadcast Media and Communication for Development. 